\title{
Diurnal, daily, seasonal and annual patterns of sap-flux-scaled transpiration from an Acacia mangium plantation in South China
}

\author{
Ling $\mathrm{MA}^{1}$, Ping $\mathrm{LU}^{2}$, Ping ZHAO ${ }^{1 *}$, Xing-quan $\mathrm{RAO}^{1}, \mathrm{Xi-an} \mathrm{CAI}^{1}, \mathrm{Xiao}$-ping ZENG ${ }^{1}$ \\ ${ }^{1}$ South China Institute of Botany, Chinese Academy of Sciences, Guangzhou 510650, P.R. China \\ ${ }^{2}$ EWL Sciences, PO Box 39443, Winnellie, NT 0821, Australia
}

(Received 11 September 2007; accepted 31 January 2008)

\begin{abstract}
-
- In this study of a 19-year-old Acacia mangium plantation with a basal area of $26.6 \mathrm{~m}^{2} \mathrm{ha}^{-1}$ in subtropical South China, whole tree sap flow was measured continuously over a two-year period and the dependence of stand sap flow $(E t)$ on environmental factors was investigated at diurnal (hourly), daily, seasonal and annual scales.

- Daytime hourly mean $E t$ was linearly correlated to photosynthetically active radiation $(Q)$ and vapor pressure deficit $(D)$ in each season during the whole study period $\left(R^{2}>0.57, P<0.001\right)$, whereas daily daytime mean $E t$ was less tightly coupled to $Q$ and $D\left(R^{2}<0.50\right)$.

- Pronounced hysteresis was observed between $E t$ and $Q$ as well as $D$ and the extent of the hysteresis varied seasonally.

- Total annual stand transpiration was higher in the first year $(244.5 \mathrm{~mm})$ than in the second year $(185.8 \mathrm{~mm})$ although rainfall was lower in the first year $(1122.4 \mathrm{~mm})$ than in the second year $(1342.5 \mathrm{~mm})$, from which it can be concluded that annual stand transpiration did not simply increase with increased annual rainfall.
\end{abstract}

Acacia mangium / sap flow / stand transpiration / environmental factor / hysteresis

Résumé - Patterns diurnes, journaliers, saisonniers et annuels de transpiration estimée d'après le flux de sève dans une plantation d'Acacia mangium du Sud de la Chine.

- Le flux de sève a été suivi dans une plantation d'Acacia mangium âgée de 19 ans avec une surface terrière de $26,6 \mathrm{~m}^{2} \mathrm{ha}^{-1}$ dans le Sud subtropical de la Chine. Les mesures ont été menées en continu pendant deux ans et la dépendance de la transpiration du peuplement (Et) par rapport aux facteurs environnementaux a été étudiée à des échelles diurnes (échelle horaire), journalières, saisonnières et annuelles.

- Pendant la journée, la moyenne horaire de Et était linéairement corrélée au Rayonnement photosynthétiquement actif $(Q)$ et au déficit de pression de vapeur d'eau $(D)$ pendant toute la période d'étude $\left(R^{2}>0,57, P<0,001\right)$ alors que la moyenne journalière de $E t$ était moins bien couplée à $Q$ et $D$ $\left(R^{2}<0,50\right)$.

- Une hystérésis marquée entre $E t$ et $Q$ en même temps que $D$ a été observé ; son amplitude variait avec la saison.

- La transpiration annuelle totale du peuplement a été plus élevée la première année $(244,5 \mathrm{~mm})$ que la deuxième année $(185,8 \mathrm{~mm})$ bien que les précipitations étaient plus faibles la première $(1122,4 \mathrm{~mm})$ que la seconde année $(1342,5 \mathrm{~mm})$. Nous en concluons que la transpiration annuelle du peuplement ne s'accroît pas simplement avec l'augmentation des précipitations annuelles.

Acacia mangium / flux de sève / transpiration du peuplement / facteurs environnementaux / hystérésis

\section{INTRODUCTION}

Acacia mangium is one of the most important plantation tree species in tropical and subtropical regions. It has been successfully used for large-scale ecological restoration projects in subtropical South China. However, there are increasing concerns about the sustainability of these fast-growing plantations in this region, especially with regard to their perceived high water use and potential impacts on the regional water balance (Shen et al., 1999; Yan et al., 2002). In contrast to its economic and ecological importance, there is only one published paper on A. mangium stand water use and this was derived from short-term studies on young plantations (Cienciala et al., 2000). Seasonal and annual patterns of transpiration and their dependence on environmental factors for mature A. mangium stands are still unreported.

\footnotetext{
* Corresponding author: zhaoping@scib.ac.cn
}

In order to develop a realistic, mechanistic understanding of patterns of tree water use, it is important to understand the response of tree water use not only at different spatial scales (azimuth or compass point, individual and stand) but also at different temporal scales (hourly, daily, seasonal and interannual) (Zeppel et al., 2006).

Environmental control of tree and stand transpiration has been well characterized during the last two decades (Arneth et al., 1996; Kelliher et al., 1992; Lu et al., 1995; Meinzer et al., 1997; Oren et al., 1999; Wullschleger et al., 2000). However, there is limited information on seasonal variation in transpiration as a response to environmental factors; information which is necessary for the evaluation and modeling of the ecophysiological processes coupled to transpiration.

The present study evaluated hourly, daily, seasonal and annual variation in stand transpiration of a mature Acacia mangium plantation and its dependence on environmental 


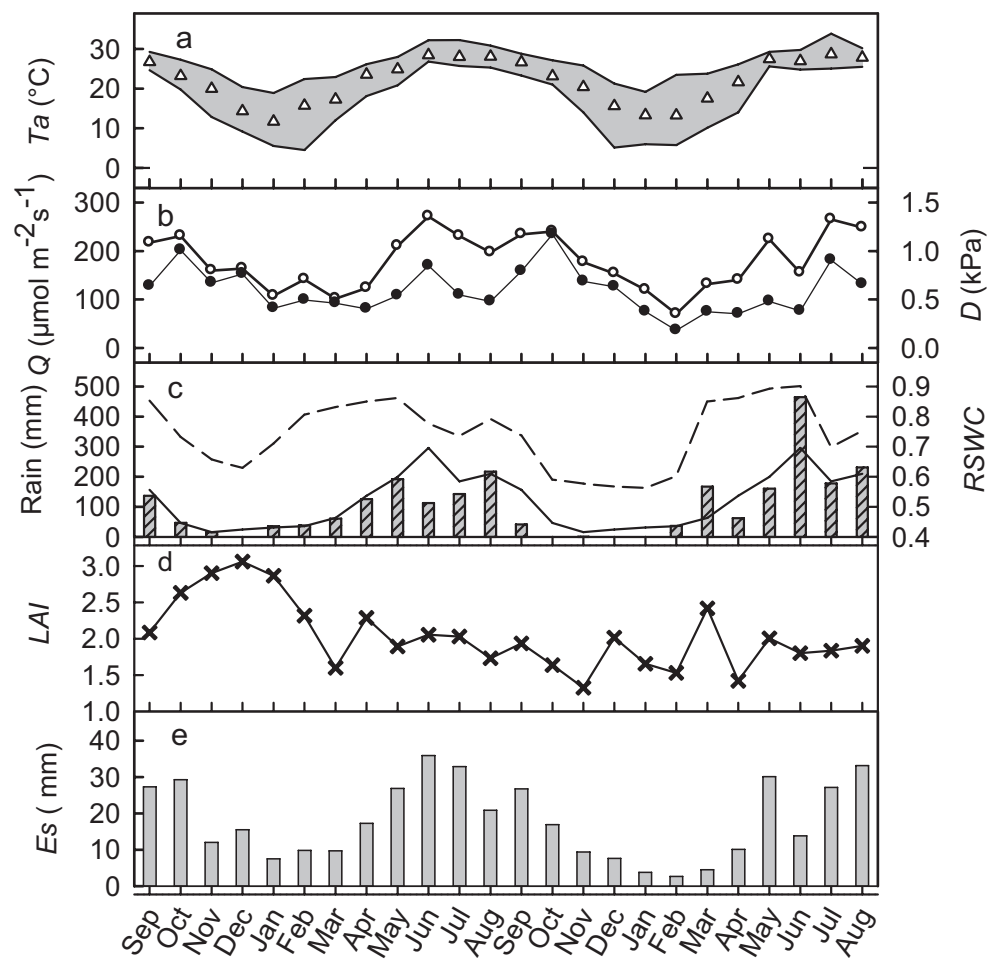

Month (2003-2005)

Figure 1. Monthly mean value of: (a) air temperature (Ta, open triangles) and range of daily mean $T a$ (gray area), (b) photosynthetically active radiation ( $Q$, open circles) and air vapor pressure deficit ( $D$, close circles), (c) actual rainfall (bars) and long-term monthly mean rainfall (line) at the study site and relative soil water content ( $R S W C$, dash line, average of three depths) in the plot, (d) LAI of the plot, and (e) monthly total stand transpiration (Es, gray bars).

factors. The main objectives of this study were to: (1) provide spatially scaled estimates of stand transpiration from long term sap flux density measurement; (2) quantify the diurnal, daily, seasonal and annual patterns of transpiration of the plantation; and (3) examine the influence of vapor pressure deficit, photosynthetically active radiation, air temperature, rainfall, leaf area index and soil water deficit on stand transpiration at each temporal scale.

\section{MATERIALS AND METHODS}

\subsection{Study site and plant materials}

The study was conducted at Heshan experimental station $\left(112^{\circ} 54^{\prime} \mathrm{E}, 22^{\circ} 41^{\prime} \mathrm{N}\right)$ of the Chinese Academy of Sciences in Guangdong Province, China. The study site is located in a subtropical monsoonal climate zone with the wet season occurring from March to August and the dry season from September to February. Average annual rainfall over the last 10 years for the Heshan station is $1400 \mathrm{~mm}$, with approximately $78 \%$ of this occurring in wet season (Fig. 1c).

The study area was in an Acacia mangium plantation that had been established 19 years prior to the beginning of the experiment (2003). A study plot, $17.5 \mathrm{~m} \times 36.6 \mathrm{~m}\left(640.5 \mathrm{~m}^{2}\right)$ was randomly selected from within the stand, the plot had 47 trees with a mean height of $15.5 \mathrm{~m}$. Plot and sample tree characteristics are summarized in Table I. The understorey vegetation was very sparse and its contribution to stand transpiration was considered to be negligible for the purposes of this study. The soil at the site was an oxisol developed from sandstone ( $\mathrm{Li}$ et al., 2005) with surface soil to a depth of $10 \mathrm{~cm}$ and subsoil for a further $50 \mathrm{~cm}$.

\subsection{Sapwood areas}

Sapwood area (As) for all trees in the plot was calculated based on an exponential regression between As and diameter at breast height (DBH, Fig. 2), established from measurements taken from ten trees outside the plot. Three to five cores were taken from each tree using an increment core borer, and sapwood depth was measured by a caliper because sapwood was visually distinct from heartwood.

\subsection{Sap flow of individual trees}

Fourteen sample trees in the plot were selected with consideration of the DBH distribution to install the Granier-type sensors for sap flow measurement (Granier, 1987; Lu et al., 2004). Sensors were made according to Oren et al. (1999). Each sensor consisted of two 20-mm-long probes which contained a copper-constantan thermocouple. The two probes were installed in the xylem $10 \mathrm{~cm}$ vertically apart at breast height. Sap flux density $\left(F_{d}, \mathrm{gH}_{2} \mathrm{O} \mathrm{m}^{-2}\right.$ sapwood s$\left.{ }^{-1}\right)$ was 
Table I. Characteristics of the plot and sample trees (As: sapwood area: DBH: diameter at breast height in $\mathrm{cm}$ ).

\begin{tabular}{|c|c|c|c|c|}
\hline & Total & $\begin{array}{c}\text { Class } 1 \\
\mathrm{DBH}<20 \mathrm{~cm}\end{array}$ & $\begin{array}{c}\text { Class } 2 \\
20 \mathrm{~cm}<\mathrm{DBH}<30 \mathrm{~cm}\end{array}$ & $\begin{array}{c}\text { Class } 3 \\
\mathrm{DBH}>30 \mathrm{~cm}\end{array}$ \\
\hline \multicolumn{5}{|l|}{ Plot $\left(640.5 \mathrm{~m}^{2}\right)$} \\
\hline Number of trees & $\begin{array}{c}47 \\
\left(734 \text { stems ha }{ }^{-1}\right)\end{array}$ & 31 & 13 & 3 \\
\hline Basal area $\left(\mathrm{m}^{2}\right)$ & $\begin{array}{c}1.704 \\
\left(26.6 \mathrm{~m}^{2} \mathrm{ha}^{-1}\right)\end{array}$ & 0.682 & 0.719 & 0.303 \\
\hline$A s\left(\mathrm{~m}^{2}\right)$ & $\begin{array}{c}0.504 \\
\left(7.87 \mathrm{~m}^{2} \mathrm{ha}^{-1}\right)\end{array}$ & 0.227 & 0.202 & 0.075 \\
\hline \multicolumn{5}{|l|}{ Sample trees } \\
\hline Number of trees & 14 & 8 & 4 & 2 \\
\hline Basal area $\left(\mathrm{m}^{2}\right)$ & 0.616 & 0.213 & 0.208 & 0.195 \\
\hline$A s\left(\mathrm{~m}^{2}\right)$ & 0.178 & 0.069 & 0.060 & 0.049 \\
\hline
\end{tabular}

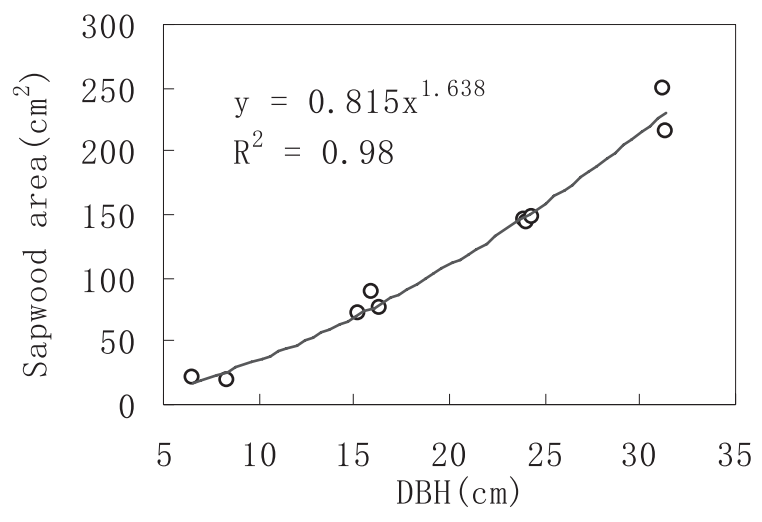

Figure 2. Relationship between sapwood area and diameter at breast height $(\mathrm{DBH})$.

calculated according to Granier (1985). The signals were scanned every $30 \mathrm{~s}$, and 10-min averages were recorded to a data logger (Delta-T Devices, Ltd., Cambridge, UK).

For Trees 1-4, $F_{d}$ was measured with sensors installed on east, south, west and north sides of the trunk while for Trees 5-14, sensors were only installed on the north side. Sensors were covered with a hard plastic box to avoid physical damage and then shielded with aluminum foil to minimize thermal interference caused by direct sunlight and wind. To ensure good measurements, new sets of sensors were reinstalled in positions $2-5 \mathrm{~cm}$ from the original holes at both the beginning and end of the dry season.

Whole-tree sap flow $\left(F, \mathrm{~g} \mathrm{~s}^{-1}\right)$ was calculated from $F_{d}$ and sapwood area $(A s)$ as:

$$
F=F_{d} \times A s .
$$

The radial variation in $F_{d}$ was considered to be negligible in this study because sapwood depth was close to $2 \mathrm{~cm}$ and $A$. mangium is a diffuse-porous species for which the radial variation in $F_{d}$ is considered to be small (Phillips et al., 1996; Lambs et al., 2006; Lu et al., 2000). Whilst this has the potential to under- or over-estimate actual values of transpiration, this is only to a small extent for trees with sapwood thickness close to $2 \mathrm{~cm}$ (Clearwater et al., 1999; Lu et al., 2004; Lüttschwager et al. 2007).
Our previous study showed that the variation in $F_{d}$ at different compass points was random for the studied trees (Ma et al., 2007). $F_{d}$ at the north side was thus assumed to be representative of $F_{d}$ of individual trees. For Trees $1-4, F_{d}$ was calculated as the mean of the values from four compass points, while for Trees $5-14, F_{d}$ was the value measured from north side.

\subsection{Stand sap flow and transpiration}

All the 47 trees in the plot were classified into 3 groups by DBH (Tab. I) using hierarchical cluster analysis (graph not shown). Sap flow measurements performed on sample trees were scaled to stand level using the equation:

$$
E t=\Sigma\left(F_{d i} \times A s_{i}\right)
$$

where $E t$ is stand sap flow $\left(\mathrm{g} \mathrm{s}^{-1}\right), F_{d i}$ is the average sap flux density of class $i, A s_{i}$ is total sapwood area in class $i$. Hourly $E t\left(\mathrm{~kg} \mathrm{~h}^{-1}\right)$ was sum of the ten-min measurements. $F_{d i}$ was calculated as:

$$
F_{d i}=\Sigma\left(A s_{s j} \times F_{d s j}\right) / \Sigma A s_{s j}
$$

where $A s_{s j}$ is sapwood area of sample tree $j, F_{d s j}$ is sap flux density of sample tree $j$.

Stand transpiration ( $E s, \mathrm{~mm} \mathrm{~d}^{-1}$ or $\mathrm{mm}$ ) was calculated from $E t$ per ground area over the respective period of time.

\subsection{Leaf area index}

Leaf area index $(L A I)$ measurements were made monthly using a CID Plant Canopy Analyzer (CID-110, CID COR., USA) under diffuse light conditions on cloudy days or at dusk.

\subsection{Weather conditions}

Air temperature $(T a)$, air relative humidity, photosynthetically active radiation $(Q)$, and rainfall were measured at the weather station of Chinese Ecosystem Research Network, $50 \mathrm{~m}$ from the studied plot 
at the same altitude. Air relative humidity and temperature were measured at $1.5 \mathrm{~m}$ height (Vaisala HMP 45A/D, Vaisala, Finland), vapor pressure deficit $(D, \mathrm{kPa})$ was calculated from $T a$ and air relative humidity (Campbell et al., 1998). $Q\left(\mu \mathrm{mol} \mathrm{m} \mathrm{m}^{-2} \mathrm{~s}^{-1}\right)$ was measured at $1 \mathrm{~m}$ height with a LI 190SA sensor (Li-Cor, Lincoln, US). Signals were scanned and recorded to a data logger synchronized to the logger for sap flow measurement.

\subsection{Soil water content}

A. mangium has a shallow root system with most roots distributed within the top $30 \mathrm{~cm}$ soil. Three volumetric soil water content sensors (ML2x, Delta-T Devices, UK) were randomly located at 20-30 cm depth in the plot. In order to show the soil water content relative to field capacity $(R S W C)$, soil bulk density $\left(\mathrm{g} \mathrm{cm}^{-3}\right)$ and field capacity were measured by sampling subsoil (at ca. $20 \mathrm{~cm}$ depth) at ten random positions in the plot. $R S W C$ was calculated as:

$$
R S W C=W_{v} \times \rho /\left(S_{d} \times W_{f}\right)
$$

where $W_{v}$ is actual volumetric soil water content $\left(\mathrm{cm}^{3} \mathrm{~cm}^{-3}\right)$ measured with ML2x sensors, $\rho$ is the density of water (presumed to be $\left.1 \mathrm{~g} \mathrm{~cm}^{-3}\right), S_{d}$ is soil bulk density $\left(\mathrm{g} \mathrm{cm}^{-3}\right)$ and $W_{f}$ is soil water content at field capacity $\left(\mathrm{g} \mathrm{g}^{-1}\right)$. It was considered that mild soil water deficit occurred when $R S W C$ was less than 0.7 and sever soil water deficit occurred when $R S W C$ was less than 0.6.

\subsection{Data analysis}

This study reports the results of sap flow and weather measurements made over two periods, namely Year 2003-2004 (from September 2003 to August 2004) and Year 2004-2005 (from September 2004 to August 2005), respectively.

All statistical analyses were performed with the SPSS software package (SPSS 13.0, SPSS, Inc., USA). Sigmaplot software (Sigmaplot 9.0, Systat Software Inc, USA) was used to make graphs.

\section{RESULTS}

\subsection{Weather conditions}

The Year 2003-2004, rainfall (Fig. 1c) generally matched the long-term pattern except that June and July rainfall was significantly below the long-term average. In Year 2004-2005, the rainfall pattern was very irregular with a much drier dry season (79 mm vs. $272 \mathrm{~mm}$ in year 2003-2004) and wetter wet season, June was excessively wet. Annual rainfall was lower in Year 2003-2004 compared with Year 2004-2005 (1 $122.4 \mathrm{~mm}$ vs. $1342.5 \mathrm{~mm}$ ). In June 2005, excessive rainfall and a number of cloudy days caused substantial reduction in $Q$ and $D$ in comparison with Year 2003-2004 (Figs. 1b, 1c).

Monthly mean $Q$ followed closely the rainfall pattern. $Q$ was high from May to December except in June 2005. Monthly mean $D$ didn't show obvious seasonality (Fig. 1b) but showed a particularly high value in November 2004.

Annual mean RSWC in Year 2003-2004 was close to that in Year 2004-2005 (0.77 vs. 0.72, Fig. 1c), but the dry season in
Year 2004-2005 (mean $R S W C=0.61$ ) was significantly drier than that in Year 2003-2004 (mean $R S W C=0.73$ ). In Year 2004-2005, severe soil water deficit $(R S W C<0.6)$ lasted for 4 months. In contrast, in Year 2003-2004, mild deficit occurred only in one month (RSWC slightly below 0.7$)$.

\subsection{Leaf area index}

Annual mean LAI was higher in Year 2003-2004 than in Year 2004-2005 (2.23 vs. 1.79). In the first half of the Year 2003-2004, LAI was significantly higher than the rest of study period $(P>0.05$, Fig. 1d).

\subsection{Diurnal patterns of sap flux density and stand sap flow in each season}

Typical examples of diurnal patterns of $F_{d}$ for each DBH class, $Q, D$ and $E t$ on a clear day in each of the four seasons of Year 2003-2004 (18 October, 24 January, 8 March, 1 July, respectively) are shown in Figure 3. Stand sap flow was the highest in summer, followed by autumn, then spring and winter. There were significant differences in the magnitude of $F_{d}$ for three classes $(P<0.05)$, i.e., $F_{d}$ for class 3 was the highest while $F_{d}$ for class 1 was the lowest, but they all followed the same diurnal trend (Figs. 3b1-3b4).

In the autumn, $F_{d}$ started immediately after sunrise, peaking when $Q$ peaked and maintaining a high value for about $3 \mathrm{~h}$ before decreasing in step with $D$ (Fig. $3 \mathrm{~b} 1$ ). In the winter, $F_{d}$ started almost $1.5 \mathrm{~h}$ later than sunrise and peaked between the peaks of $Q$ and $D$, then declined in step with $D$ after 17:00 (Fig. 3b2). In the spring, $F_{d}$ started $1 \mathrm{~h}$ later than sunrise and peaked between the peak of $Q$ and $D$ after which a gradual decline was observed (Fig. 3b3). In the summer, $F_{d}$ started immediately after sunrise and showed a mid-day depression between peaks of $Q$ and $D$ (Fig. 3b4)

\subsection{Daily patterns of stand sap flow in winter and summer}

Figure 4 shows the pattern of daily mean daytime value of $E t$ and environmental factors in a typical winter (February) and summer (July) month in Year 2003-2004 and Year 2004-2005 respectively. Over the two years, monthly mean Et in July was always significantly higher than that in February. $E t$ in February and July in Year 2003-2004 was significantly higher than the corresponding month in Year 2004-2005. In February 2004, rainfall occurred at the beginning of the month, and $R S W C$ was higher than 0.7 throughout the month indicating non-deficit soil water conditions. In February 2005, almost no rainfall occurred at the beginning of the month and $R S W C$ was mostly below 0.6 indicating severe soil water deficit. In addition, $Q$ and $D$ were both higher in February 2004 than in February 2005.

In July 2004, rainfall was distributed intermittently throughout the month and no soil water deficit occurred. In 


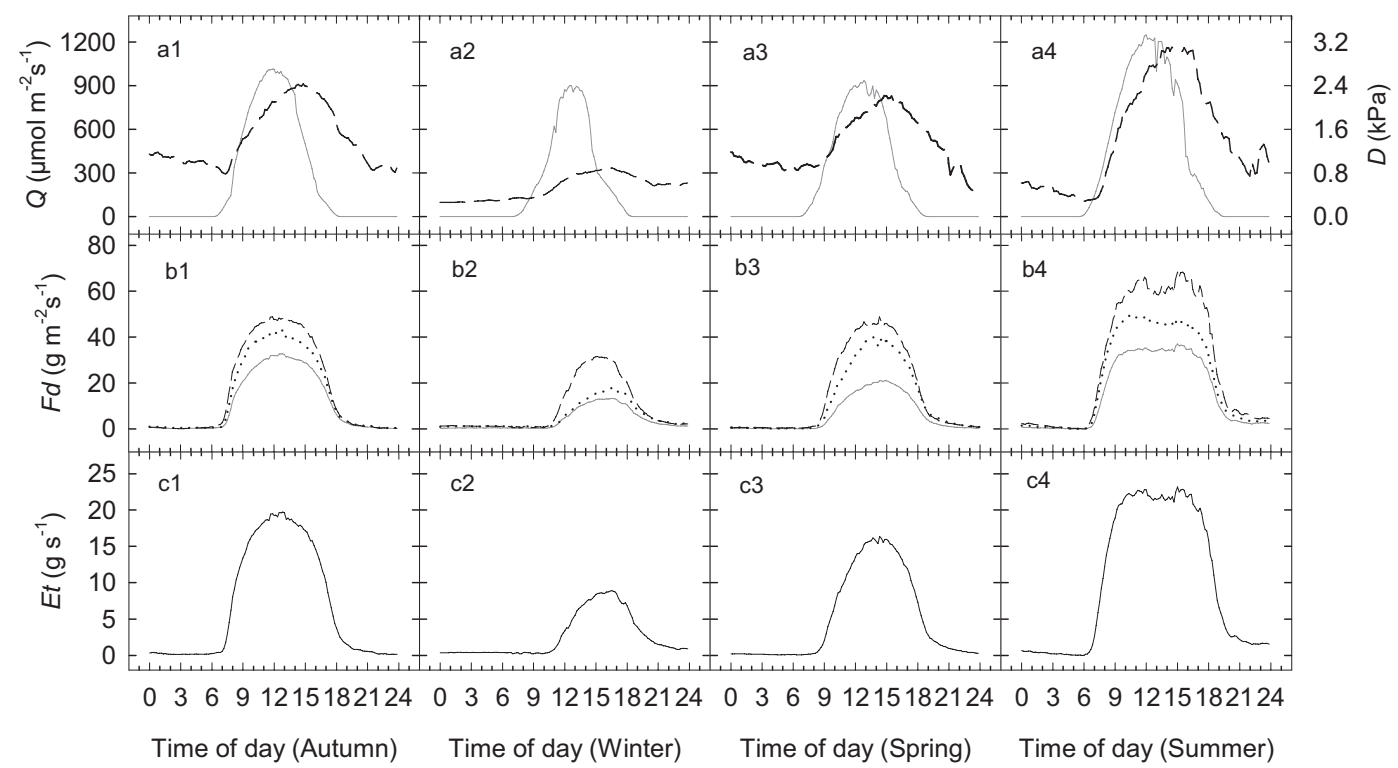

Figure 3. Diurnal patterns of: (a) photosynthetically active radiation $(Q$, solid line) and air vapor pressure deficit ( $D$, dashed line), (b) mean sap flux density $\left(F_{d}\right)$ of DBH class 1 (solid line), class 2 (dotted line) and class 3 (dashed line), and (c) stand sap flow (Et) on a clear day of each season. All data were the means over 10 min periods.

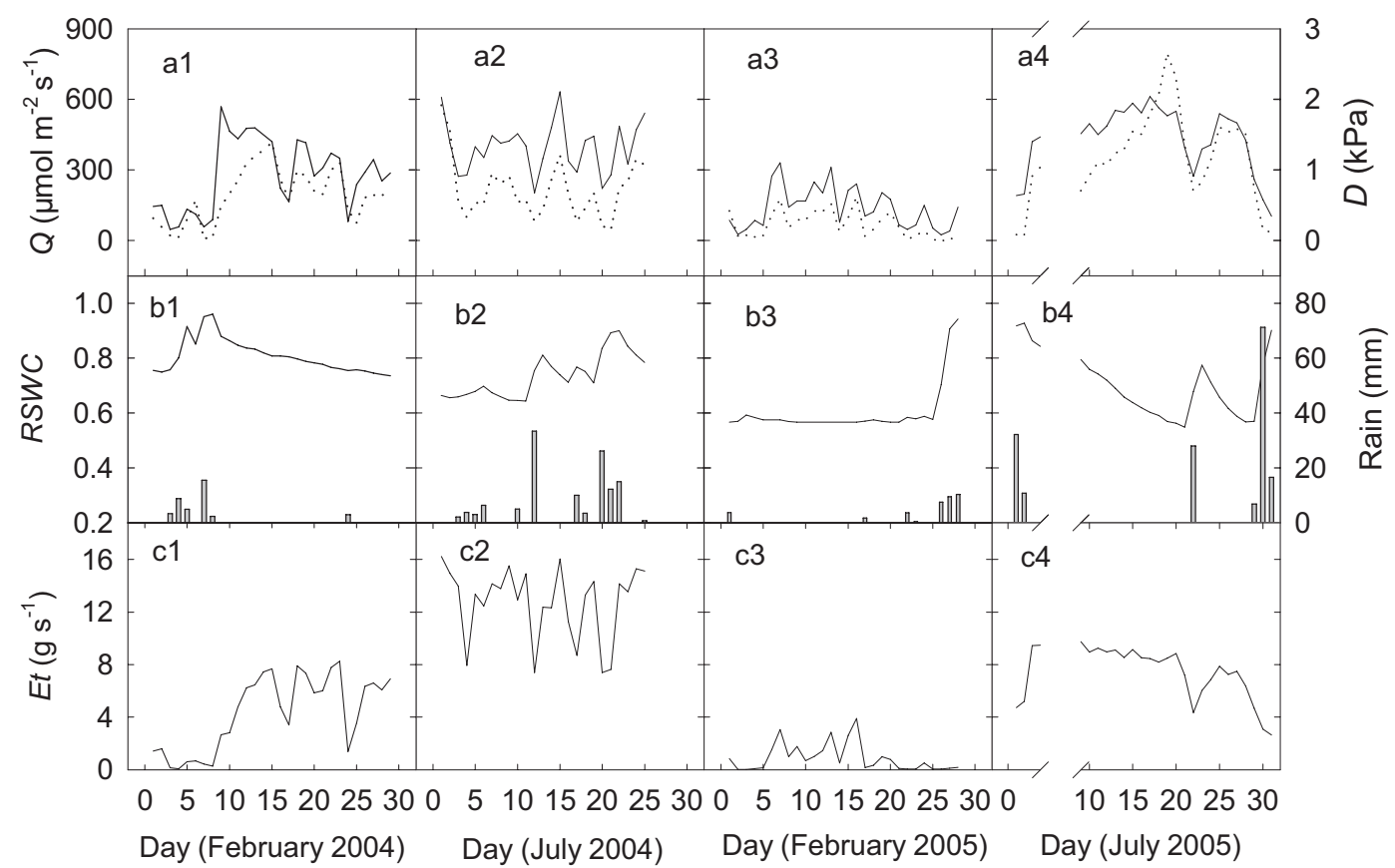

Figure 4. Daily patterns of: (a) mean daytime photosynthetically active radiation $(Q$, solid line) and air vapor pressure deficit $(D$, dotted line), (b) relative soil water content $(R S W C$, line) and rainfall (bars), and (c) daily mean daytime stand sap flow (Et) in a typical month of winter and summer in Year 2003-2004 and Year 2004-2005 respectively. 
Table II. Summary of the interannual changes in rainfall and transpiration.

\begin{tabular}{lcc}
\hline & Year 2003-2004 & Year 2004-2005 \\
\hline Rainfall $(\mathrm{mm})$ & 1122.4 & 1342.5 \\
Maximum daily transpiration $\left(\mathrm{mm} \mathrm{d}^{-1}\right)$ & 1.64 & 0.92 \\
Annual stand transpiration $(\mathrm{mm})$ & 244.5 & 185.8 \\
\hline
\end{tabular}

Table III. The level of stand sap flow $(E t)$ dependence on photosynthetically active radiation $(Q)$ and vapor pressure deficit $(D)$ in each season during the two years.

\begin{tabular}{|c|c|c|c|c|c|}
\hline \multirow{2}{*}{ Regression } & \multirow{2}{*}{ Season } & \multicolumn{2}{|c|}{ Year 2003-2004 } & \multicolumn{2}{|c|}{ Year 2004-2005 } \\
\hline & & $R^{2}$ & $P$ & $R^{2}$ & $P$ \\
\hline \multirow{4}{*}{$E t$ vs. $Q$} & Autumn & 0.767 & $<0.001$ & 0.740 & $<0.001$ \\
\hline & Winter & 0.285 & $<0.001$ & 0.344 & $<0.001$ \\
\hline & Spring & 0.570 & $<0.001$ & 0.713 & $<0.001$ \\
\hline & Summer & 0.707 & $<0.001$ & 0.714 & $<0.001$ \\
\hline \multirow{4}{*}{$E t$ vs. $D$} & Autumn & 0.584 & $<0.001$ & 0.774 & $<0.001$ \\
\hline & Winter & 0.744 & $<0.001$ & 0.869 & $<0.001$ \\
\hline & Spring & 0.666 & $<0.001$ & 0.687 & $<0.001$ \\
\hline & Summer & 0.581 & $<0.001$ & 0.677 & $<0.001$ \\
\hline \multirow{4}{*}{$E t$ vs. $Q+D$} & Autumn & 0.924 & $<0.001$ & 0.958 & $<0.001$ \\
\hline & Winter & 0.784 & $<0.001$ & 0.880 & $<0.001$ \\
\hline & Spring & 0.843 & $<0.001$ & 0.892 & $<0.001$ \\
\hline & Summer & 0.892 & $<0.001$ & 0.919 & $<0.001$ \\
\hline
\end{tabular}

July 2005, evaporative demand as represented by $Q$ and $D$ was high and $R S W C$ fell below 0.6 over prolonged period indicating severe short-term drought.

\subsection{Annual patterns of stand transpiration}

The annual patterns of monthly mean $E s$ followed closely the variation in $Q$ (Figs. 1b, 1e) with low Es over the period from November to April and high Es during the summer. Es in Year 2003-2004 (244.5 mm) was higher than that in Year 2004-2005 (185.8 mm). Maximum daily stand transpiration was $1.64 \mathrm{~mm}$ in Year 2003-2004 which was almost $80 \%$ higher than that in Year 2004-2005 (Tab. II).

\subsection{Dependence of $E t$ on environmental factors}

To avoid the influence of a wet canopy on the energy budget, relationships between transpiration and environmental factors were analyzed using daytime hourly values excluding the data from rainy days and the day following rain. In this study, dependence of $E t$ on environmental factors was evaluated both with and without taking consideration of hysteresis between hourly sap flux and $Q$ and $D$.

The correlations of daytime hourly mean $E t$ with $Q$ and $D$ in each season, without taking consideration of hysteresis, are shown in Figure 5 and the levels of the dependence are shown in Table III. There was a marked seasonal response in hourly
$E t$ to $Q$ and $D$. Generally for a given $Q$ or $D, E t$ was higher during the wet season than during the dry season. $Q$ or $D$ alone explained $57.0 \%-86.9 \%(P<0.001)$ of the variation in $E t$ in most seasons except for winter. During winter, stand sap flow was highly dependent on vapor pressure deficit but very little on radiation. With a combination of $Q$ and $D, 78.4 \%-95.8 \%$ $(P<0.001)$ of the variation in hourly $E t$ was explained, indicating strong coupling of $E t$ to the drivers of transpiration at the diurnal scale. The slopes for the regressions of $E t$ dependent on $Q$ or $D$ were higher in Year 2003-2004 than in Year 2004-2005.

In fact, the hysteresis between hourly sap flux and $Q$ and $D$ within a day influenced the coupling of $E t$ with the drivers of transpiration (here represented by $Q$ and $D$ ). Since the diurnal trends of different tree sizes were similar in each season (Figs. 3b1-3b4), the difference in hysteresis between individual trees was ignored. The hysteresis between $E t$ and $Q$ and $D$ was evaluated by shifting diurnal time series (10-min value) to obtain the best fit. Hysteresis for either $Q$ or $D$ in each season is shown in Tab. IV.

Taking into consideration of the hysteresis substantially increased the percentage of the variation in $E t$ explained by $Q$ or $D$ alone: $75.8 \%-99.1 \%$ by $Q$ alone, and $82 \%-98 \%$ by $D$ alone during whole study period (data not shown).

When $E t$ dependence on $Q$ and $D$ was evaluated using daily mean daytime values rather than diurnal daytime hourly values, the percentage of the variation in Et explained by $Q$ or $D$ alone was much reduced: less than $50 \%$ of the variation in $E t$ was explained by $Q$ or $D$ alone in most seasons and $50.7 \%-$ 

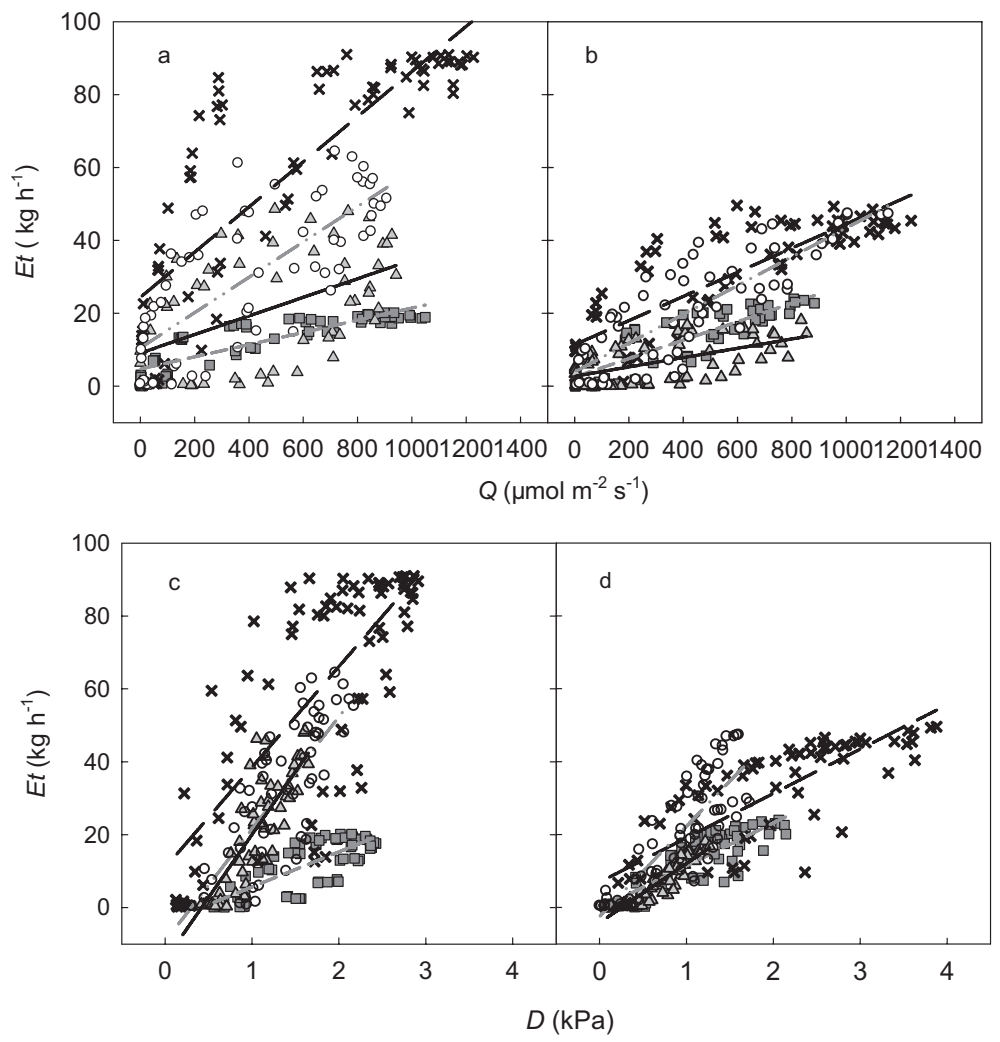

Figure 5. Hourly mean daytime values of stand sap flow $(E t)$ in relation to photosynthetically active radiation $(Q)$ and air vapor pressure deficit $(D)$ in autumn $(\square)$, winter $(\Delta)$, spring $(\circ)$ and summer $(\boldsymbol{X})$ during Year 2003-2004 (a, c), and Year 2004-2005 (b, d) respectively. Regression lines were also shown: short dash lines, solid lines, dash dot lines and long dash lines represent the relationships in autumn, winter, spring and summer, respectively. Data were retrieved from 5 clear days in each season.

$80.1 \%$ was explained by a combination of $Q$ with $D$ during the whole study period.

\section{DISCUSSION}

\subsection{Dependence of $E t$ on $Q$ and $D$}

In this study, daytime hourly $E t$ was mostly linearly correlated to $Q$ or $D$ in each season (Fig. 5), but substantial hysteresis in the relationships between $E t$ and $Q$ and $D$ was observed (Tab. III). Taking hysteresis into consideration markedly decreased uncertainty in the variation in Et. The reduced slopes of the above regressions in Year 2004-2005 were most likely caused by extended periods of soil water deficit in the dry season and intermittent drought during the wet season. In fact, on the selected 5 clear days in each season in Year 20032004 the sample trees did not experience any soil water deficit, but in Year 2004-2005, the trees were exposed to severe soil water deficit $(R S W C<0.6)$ in all seasons except spring. Indeed, the slope of the regression in spring 2004-2005 was only marginally lower than that of 2003-2004.

Cienciala et al. (2000) also reported tight coupling of transpiration to environmental factors for a young $A$. mangium stand $\left(R^{2}=0.79\right.$ and 0.85 for $Q$ and $D$, respectively), but in
Table IV. Hysteresis in the relationships between $E t$ and $Q$ and $D$ in each season. Data were the mean values of 5 clear days in each season.

\begin{tabular}{lcc}
\hline \multirow{2}{*}{ Season } & \multicolumn{2}{c}{ Hysteresis (min) } \\
\cline { 2 - 3 } & $E t$ vs. $Q$ & Et vs. $D$ \\
\hline Autumn & 60 & 60 \\
Winter & 120 & 20 \\
Spring & 70 & 50 \\
Summer & 50 & 70 \\
\hline
\end{tabular}

their study, no significant hysteresis was observed. The difference between our results and theirs might be caused by (1) difference in climatic conditions between the study sites, and (2) A. mangium might have established different water use strategies in response to the local climate. When $Q$ and $D$ were combined $78.4 \%-95.8 \%$ of the variation in hourly $E t$ was explained, even when hysteresis was not taken into consideration. This clearly indicates a tight coupling of $E t$ to the drivers of transpiration at diurnal scales in each season.

Meinzer et al. (1997) suggested that the extent of diurnal hysteresis in the relationships between $E t$ and $Q$ and $D$ was determined by the manner in which $Q$ and $D$ co-varied 
throughout the day because the variation of $Q$ and $D$ was out of phase on clear days. This explanation might be valid for their study, but does not adequately explain the seasonality of hysteresis observed in the present study. The extent of hysteresis between $E t$ and $Q$ was larger in cold than in hot seasons whereas the opposite result was observed for $D$ (Tab. IV). Short-term severe soil water deficit in July 2005 did not significantly influence hysteresis (data not shown). We suggest that the seasonal variation in $T a$ could have played an important role in seasonal variation of hysteresis. However, more measurements are needed to verify this.

Daily mean daytime $E t$ increased with increasing $Q$ and $D$ in most seasons of the study period. But daily mean daytime $E t$ was less tightly coupled to either $Q$ or $D$ in each season in comparison with daytime hourly mean $E t$ in this study, this might be caused by the daily changes in $R S W C$ and reduced range of the variation of the values.

\subsection{Daily stand transpiration (Es)}

Annual mean daily Es in our study was $0.59 \mathrm{~mm}$ during the whole study period. There is only one other published sap flow study from a young (9.5 years old) A. mangium plantation in Borneo, Malaysia (Cienciala et al., 2000). Results from their plot 1 are arguably the only ones comparable to ours. In the present study, the highest daily $E s$ was $1.64 \mathrm{~mm} \mathrm{~d}^{-1}$, which was $61 \%$ of the maximum daily Et measured by Cienciala et al. (2000). A comparison of stand transpiration between different plantations is difficult, especially when the stands are geologically distant and no potential evapotranspiration information is available. Taking into consideration: the absence of values for sapwood area per ha and $L A I$ in Cienciala et al. (2000); that basal area was larger at our site $\left(26.6 \mathrm{~m}^{2} \mathrm{ha}^{-1}\right.$ vs. $18.6 \mathrm{~m} \mathrm{ha}^{-1}$ ); and sapwood areas for a typical tree of DBH of $25 \mathrm{~cm}$ were comparable $\left(160 \mathrm{~cm}^{2}\right.$ in Cienciala et al., 2000 vs. $155 \mathrm{~cm}^{2}$ in ours); the main cause of the low stand transpiration was probably the increasing age of our stand of trees. A decrease in Es due to aging was reported by Delzon et al. (2005). Differences in drivers of transpiration between the two sites could have also contributed to the difference in Es because the high values reported by Cienciala et al. (2000) were obtained in August when drivers of transpiration were usually high and no soil water deficit was observed.

The decoupling coefficient $(0 \leq \Omega \leq 1)$ introduced by Jarvis and McNaughton (1986) was largely used to evaluate the stomatal control on canopy transpiration. One implication of $\Omega$ approaching 0 is that the aerodynamic conductance was particularly high relative to stomatal conductance and vice versa. In this study, $\Omega$ was $<0.2$ (unpublished data) indicating relatively low stomatal conductance. Cienciala et al. (2000) suggested that $\Omega$ should be high for their stand, this implied relatively high stomatal conductance. From the above discussion we suggest that beside the differences in climatic conditions and planting density between the two sites, aging effect could have contributed to the decline in tree transpiration in the present study.

\subsection{Seasonal change in stand transpiration (Es)}

Strong seasonality in Es was observed throughout this study (Figs. 3c, 4c, and 5) with $E t(E s)$ being larger in the summer than in the winter. Such seasonality in tree water use is generally observed in temperate and tropical systems because of large changes in Ta, $Q, D$ and soil water content (Morris et al., 1999; Zeppel et al., 2006). Several reasons can explain this. First, drivers of transpiration (mainly $Q$ and $D$ ) were always greater in summer than in winter. Second, in subtropical South China, summer is a wet season while winter is a dry season, soil water deficit occurring in autumn and winter inevitably reduces $E s$. The influence of $Q, D, T a$ and soil water content on tree transpiration is well documented (O'Grady et al., 2000; Oren et al., 1999; Wullschleger et al., 2001). In this study, in autumn, although the evapotranspiration drivers $(Q$ and $D)$ were still high, rainfall rarely occurred and $R S W C$ was usually low. Contrarily, in spring, frequently rainfall improved the soil water content but $Q, D$ and $T a$ were relatively low, so the magnitude of $E s$ in autumn and spring were between that in winter and summer.

\subsection{Interannual change in stand transpiration (Es)}

Total annual Es in Year 2003-2004 was 32\% higher than in Year 2004-2005 despite a 16\% reduction in rainfall in Year 2003-2004. Whilst a reduction in LAI appears to be the main factor, because monthly averaged $L A I$ was reduced by 20\% from Year 2003-2004 to Year 2004-2005 while Es reduced by $24 \%$; considering that $E s$ only contributed very little (14.3\%) to the annual total Es during the months with high $L A I$ (November and December 2003 and January 2004), reduction in $L A I$ is unlikely to be the main cause.

Deviation from the long term average rainfall pattern in most months in Year 2004-2005 seems to be the key factor. In Year 2004-2005 severe soil water deficit developed and lasted for four months during the dry season, and excessive rainfall and severe short-term drought occurred during the wet season. For instance, Es in June of Year 2003-2004 contributed 14.7\% to total annual Es while Es in June of Year 2004-2005 only contributed $9.8 \%$ because of the excessive and frequent rainfalls. Excessive rainfall tends to be lost by drainage or runoff (Lane et al., 2004) and frequent rainfalls attenuate transpiration (Krauss et al., 2007). Thus, we concur with the observation that annual stand transpiration did not simply increase with rainfall. On the contrary, excess rainfall with large number of overcast and rainy days can significantly reduce annual transpiration.

The 19-year-old stand of A. mangium used in this study was considered to be in decline, with an annual transpiration of $186-225 \mathrm{~mm}$, which was only about $14-20 \%$ of the annual rainfall $(1122-1343 \mathrm{~mm})$ at the study site. Such low stand transpiration is unlikely to impact on the regional water balance. However, it is evident that a younger, flourishing plantation would have much higher transpiration.

Even taking the largely overestimated annual transpiration of $986 \mathrm{~mm}$ (Cienciala et al., 2000) from a stand with a higher 
density (1020 stems ha ${ }^{-1}$ ), at its flourishing stage (9-year-old), and in a region with much higher annual rainfall $(3280 \mathrm{~mm})$, as an indicator of the potential transpiration of a young stand in our region; this overestimated transpiration would still fall below the average rainfall in our region. Therefore, it is expected that planting A. mangium at a density similar to that found in the present study would be unlikely to cause major concern for the regional water balance.

\section{CONCLUSION}

1. Annual mean daily stand transpiration was $0.59 \mathrm{~mm} \mathrm{~d}^{-1}$ and maximum daily transpiration was $1.64 \mathrm{~mm} \mathrm{~d}^{-1}$.

2. Hourly mean stand sap flow was highly coupled to photosynthetically active radiation and vapor pressure deficit in each season but its dependence on these factors varied seasonally. During the winter, stand sap flow was highly dependent on vapor pressure deficit but very little on radiation.

3. Marked hysteresis in the relationships between stand sap flow and photosynthetically active radiation and vapor pressure deficit was observed and the extent of the hysteresis varied seasonally.

4. Annual stand transpiration did not simply increase with increased annual rainfall. On the contrary, excess rainfall in the wet season as well as short term drought in the dry season can significantly reduce annual stand transpiration.

Acknowledgements: We sincerely acknowledge Dr. Zhi-an Li for his help and advice on measuring relative soil water content, Dr. Tim Blumfield for the correction of the text. The study was supported by National Natural Science Foundation of China (30428022, 30270239 and 30770328), the Natural Science Foundation of Guangdong Province (031265, 07006917), and the Knowledge Innovation Program of the Chinese Academy of Sciences (KSCX2-SW-133).

\section{REFERENCES}

Arneth A., Kelliher F.M., Bauer G., Hollinger D.Y., Byers J.N., Hunt J.E., McSeveny T.M., Ziegler W., Vygodskaya N.N., Milukova I., Sogachov A., Varlagin A., and Schulze E.-D., 1996. Environmental regulation of xylem sap flow and total conductance of Larix gmelinii trees in eastern Siberia. Tree Physiol. 16: 247-255.

Campbell G.S. and Norman J.M., 1998. An introduction to environmental biophysics (2nd ed.), Springer - Verlag, NewYork, 286 p.

Cienciala E., Kučera J., and Malmer A., 2000. Tree sap flow and stand transpiration of two Acacia mangium plantations in Sabah, Borneo. J. Hydrol. 236: 109-120.

Clearwater M.J., Meinzer F.C., Andrade J.L., Goldstein G., and Holbrook N.M., 1999. Potential errors in measurement of nonuniform sap flow using heat dissipation probes. Tree Physiol. 19: 681-687.

Delzon S. and Loustau D., 2005. Age-related decline in stand water use: sap flow and transpiration in a pine forest chronosequence. Agric. For. Meteorol. 129: 105-119.

Granier A., 1985. Une nouvelle méthode pour la mesure du flux de sève brute dans le tronc des arbres. Ann. Sci. For. 42: 193-200.

Granier A., 1987. Evaluation of transpiration in a Douglas fir stands by means of sap flow measurements. Tree Physiol. 3: 309-320.

Jarvis P.G. and McNaughton K.G., 1986. Stomatal control of transpiration: scaling up from leaf to region. Adv. Ecol. Res. 15: 1-49.
Kelliher F.M., Köstner B.M.M., Hollinger D.Y., Byers J.N., Hunt J.E., McSeveny T.M., Meserth R., Weir P.L., and Schulze E.-D., 1992. Evaporation, xylem sap flow, and tree transpiration in a New Zealand broad-leaved forest. Agric. For. Meteorol. 62: 53-73.

Krauss K.W., Young P.J., Chambers J.L., Doyle T.W., and Twilley R.R., 2007. Sap flow characteristics of neotropical mangroves in flooded and drained soils. Tree Physiol. 27: 775-783.

Lambs L., Loubiat M., Girel J., Tissier J., Peltier J., and Marigo G., 2006. Survival and acclimatation of Populus nigra to drier conditions after damming of an alpine river, southeast of France. Ann. For. Sci. 63: 377-385.

Lane P.N.J., Morris J., Zhang N.N., Zhou G.Y., Zhou G.Y., and Xu D.P., 2004. Water balance of tropical eucalypt plantations in south-eastern China. Agric. For. Meteorol. 124: 253-267.

Li Z.A., Zou B., Xia H.P., Ding Y.Z., Tan W.N., and Ma Z.R., 2005. Effect of fertilizer and water content on $\mathrm{N}_{2} \mathrm{O}$ emission from three plantation soils in south China. J. Environ. Sci. 17: 970-976.

Lu P., Biron P., Bréda N., and Granier A., 1995. Water relations of adult Norway spruce (Picea abies (L.) Karst.) under soil drought in the Vosges mountains: Water potential, stomatal conductance and transpiration. Ann. Sci. For. 52: 117-129.

Lu P., Muller W.J., and Chacko E.K., 2000. Spatial variations in xylem sap flux density in the trunk of orchard-grown, mature mango trees under changing soil water conditions. Tree Physiol. 20: 683-692.

Lu P., Urban L., and Zhao P., 2004. Granier's Thermal Dissipation Probe (TDP) method for measuring sap flow in trees: theory and practice. Acta Botanica Sinica 46: 631-646.

Lüttschwager D. and Remus R., 2007. Radial distribution of sap flux density in trunks of a mature beech stand. Ann. For. Sci. 64: 431-438.

Ma L., Rao X.Q., Zhao P., Lu P., Cai X.A., and Zeng X.P., 2007. Diurnal and seasonal changes in whole-tree transpiration of Acacia mangium. Journal of Beijing Forestry University 29: 67-73.

Meinzer F.C., Hinckley T.M., and Ceulemans R., 1997. Apparent responses of stomata to transpiration and humidity in a hybrid poplar canopy. Plant Cell Environ. 20: 1301-1308.

Morris J.D. and Collopy J.J., 1999. Water use and salt accumulation by Eucalyptus camaldulensis and Casuarina cunninghamiana on a site with shallow saline groundwater. Agric. Water Manage. 39: 205-227.

O'Grady A.P., Chen X., Eamus D., and Hutley L.B., 2000. Composition, leaf area index and standing biomass of eucalypt open forests near Darwin in the Northern Territory, Australia. Aust. J. Bot. 48: 629638.

Oren R., Philips N., Ewers B.E., Pataki D.E., and Megonigal J.P., 1999. Sap-flux-scaled transpiration responses to light, vapor pressure deficit, and leaf area reduction in a flooded Taxodium distichum forest. Tree Physiol. 19: 337-347.

Phillips N., Oren R., and Zimmermann R., 1996. Radial patterns of xylem sap flow in non-, diffuse- and ring-porous tree species. Plant Cell Environ. 19: 983-990.

Shen W.J., Zhou G.Y., Peng S.L., Yu Z.Y., Lin Y.B., and Zeng Y.T., 1999. Surface runoff in five ecosystems of Heshan subtropical hilly land. J. Trop. Subtrop. Bot. 7: 273-281.

Wullschleger S.D., Hanson P.J., and Todd D.E., 2001. Transpiration from a multi-species deciduous forest as estimated by xylem sap flow techniques. For. Ecol. Manage. 143: 205-213.

Wullschleger S.D., Wilson K.B., and Hanson P.J., 2000. Environmental control of whole-plant transpiration, canopy conductance and estimates of the decoupling coefficient for large red maple trees. Agric. For. Meteorol. 104: 157-168.

Yan J.H., Zhou G.Y., and Lin Y.B., 2002. The regulation on water and heat factors during the restoration process of an Acacia mangium plantation. Acta Phytoecologica Sinica 26: 465-472.

Zeppel M.J.B., Yunusa I.A.M., and Eamus D., 2006. Daily, seasonal and annual patterns of transpiration from a stand of remnant vegetation dominated by a coniferous Callitris species and a broad-leaved Eucalyptus species. Physiol. Plantarum 127: 413-422. 